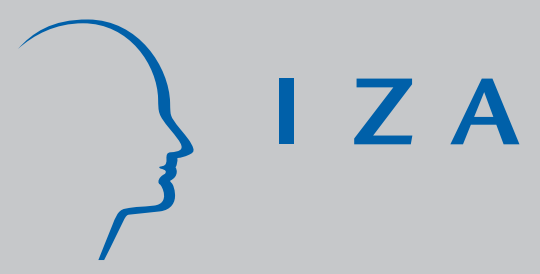

IZA DP No. 3964

American Education in the Age of Mass Migrations 1870-1930

Fabrice Murtin

Martina Viarengo

J anuary 2009 


\title{
American Education in the Age of Mass Migrations 1870-1930
}

\author{
Fabrice Murtin \\ Stanford University, \\ CEE, London School of Economics \\ and CREST-INSEE \\ Martina Viarengo \\ Harvard University, \\ London School of Economics \\ and IZA
}

Discussion Paper No. 3964
January 2009

IZA
P.O. Box 7240
53072 Bonn
Germany

Phone: +49-228-3894-0

Fax: +49-228-3894-180

E-mail: iza@iza.org

\begin{abstract}
Any opinions expressed here are those of the author(s) and not those of IZA. Research published in this series may include views on policy, but the institute itself takes no institutional policy positions.

The Institute for the Study of Labor (IZA) in Bonn is a local and virtual international research center and a place of communication between science, politics and business. IZA is an independent nonprofit organization supported by Deutsche Post Foundation. The center is associated with the University of Bonn and offers a stimulating research environment through its international network, workshops and conferences, data service, project support, research visits and doctoral program. IZA engages in (i) original and internationally competitive research in all fields of labor economics, (ii) development of policy concepts, and (iii) dissemination of research results and concepts to the interested public.
\end{abstract}

IZA Discussion Papers often represent preliminary work and are circulated to encourage discussion. Citation of such a paper should account for its provisional character. A revised version may be available directly from the author. 


\section{ABSTRACT}

\section{American Education in the Age of Mass Migrations 1870-1930*}

This paper derives original series of average years of schooling in the United States 18701930, which take into account the impact of mass migrations on the US educational level. We reconstruct the foreign-born US population by age and by country of origin, while combining data on the flow of migrants by country and the age pyramids of migrants by country. Then we use original data on educational attainment in the nineteenth century presented in Morrisson and Murtin (2008) in order to estimate the educational level of US immigrants by age and by country. As a result, our series are consistent with the first national estimates of average schooling in 1940. We show that mass migrations have had a significant but modest impact on the US average educational attainment. However, the educational gap between US natives and immigrants was large and increased with the second immigration wave, a phenomenon that most likely fostered the implementation of restrictive immigration rules in the 1920s.

JEL Classification: $\quad$ 12, J24, N70, O1

Keywords: education, migrations, economic history, economic development research

Corresponding author:

Martina Viarengo

Program on Education Policy and Governance

John F. Kennedy School of Government

Harvard University

79 John F. Kennedy Street, Taubman 304

Cambridge, MA 02138

USA

E-mail: Martina_Viarengo@ksg.harvard.edu

\footnotetext{
* This paper has benefited from useful insights by Avner Greif, Claude Diebolt, Claudia Goldin, PierreCyrille Hautcoeur, Christian Morrisson, Paul E. Peterson, Hugh Rockoff, Gianni Toniolo, Antonio Wendland, Jeffrey Williamson, Gavin Wright, as well as seminar participants at Rutgers University, Stanford University and Tor Vergata University. Murtin ackowledges financial support from the Mellon Foundation when he was hosted by Stanford Centre for the Study of Poverty and Inequality, as well as from the EU RTN Migration network when he was hosted by Tor Vergata University. Viarengo gratefully acknowledges the support of the Harvard's Program on Education Policy and Governance.
} 


\section{Introduction}

In the economic history literature most of the existing studies on the mass migrations of the nineteenth century have focused on the evolution of migration flows, their economic determinants and their consequences in both the country of origin and the country of destination.

A more limited stream of the literature has looked at the characteristics of migrants. In particular, an analysis of the composition of the stock of skills and knowledge of the migrant population has never been achieved so far for that period. In this paper, we aim to estimate the average educational level of US natives as well as of immigrants over the period 1870-1930, hence obtaining the first consistent series of average education among the whole US population.

This issue is of great importance in the context of developing an understanding of the world economy in the first globalization era. As surveyed by Hatton and Williamson (1998, 2005) and O'Rourke and Williamson (2000), mass migrations have had many economic consequences on both the immigrant and the emigrant countries, shifting an important part of the labor force from the labor-abundant Old World to the labor-scarce New World. The United States have absorbed the bulk of European emigration between 1820 and 1920, around 60\%. The massive flow of workers across the ocean had potentially some significant consequences on the skill composition of the population. As the US were among the world leaders in terms of literacy in 1870 , it is true that migrants could have been viewed as being unskilled by US standards. 
In order to quantify the discrepancy in educational attainment between US immigrants and native Americans, we use perpetual inventory methods to infer average years of schooling among both populations, relying on Morrisson-Murtin (2008) education database 1870-2000. As a result, we estimate the impact of mass migrations on average years of schooling in the US population, and we find that our 1870-1930 series are consistent with the first national estimate of average years of schooling in 1940. In fact, this paper shows that the overall impact of migrations has been at maximum a diminution of 0.8 average years of schooling among the population aged $15-64$, or 10 percentage points of enrolment rate in 8 years-long Primary. This gap is significant but still modest, because the 15-64 immigrants population never represented more than $25 \%$ of the US workforce. However, it is true that the gap in average education was large between US natives and immigrants. Among adults aged 15-39, In particular, it peaked with the second wave of immigration at 4.27 average years of schooling in 1920, which roughly represent a gap of more than 50 percentage points of Primary enrolment rate. To draw a comparison, when native Americans had on average completed Primary and a few years of high school, immigrants had completed slightly more than half of Primary. With the start of the high school movement at the same period, this gap had become unsustainable and was certainly an important motive behind the 1920s Immigration Quotas, which marked the start of selective immigration to the US.

The paper proceeds as follows. Section two will describe briefly the literature on the mass migrations of the nineteenth and early twentieth centuries. Then we 
explain in section three how we have reconstructed the US population by age and by country of origin using perpetual inventory methods. We present the data, discuss the assumptions behind the construction of our series, and present the results. Last section concludes.

\section{Mass migrations to the United States 1820-1930}

It is largely acknowledged in the existing literature that over the nineteenth and the early twentieth century one of the fundamental factors leading Europeans to emigrate was land abundance in the New World. Certainly the pressure of a growing population on a fixed amount of agricultural land play a key role in this decision as emphasized by Livi Bacci (1991). Moreover, in the late nineteenth century many holdings were subdivided in countries like Italy and this made it more difficult for families to be self-sustained. This argument is supported by the empirical evidence provided by Hatton and Williamson (1998, p.112) who find the share of the labor force in agriculture to be a highly significant determinant of the decision to migrate in Southern European countries, suggesting that the limited opportunities in the lands of Southern Europe led to emigration.

Overall, immigration to the United States gradually shifted from Northern and Western European countries to the Southern and Eastern ones in the late nineteenth century. The economic and political conditions in the countries of departure can provide an explanation for this timing. Also, the innovation of the steam shipping on the North Atlantic and the reduction in the cost of the journey clearly 
played a key role. It became easier over time for poorer people to make the move, as well as to go back to their home country after some time. In this regard, immigration to the United States from the more peripherical regions of Europe often became temporary in the late nineteenth century.

This is confirmed by Figure 1 that depicts the arrivals and the departures of alien passengers as well as net immigration ${ }^{1}$. The height of the US net flow of immigrants is reached before the beginning of the Great War and the recovery from the war brings an increase in the flow of net immigration, which nevertheless does not reach the pre-war levels.

Figures 2 and 3 depict the distribution by country of US immigrants in relative terms, as described by HSUS. As previously described in other studies (Baines, 1991; Hatton and Williamson, 1998), two waves of mass immigration took place. In the first one ranging roughly over the whole nineteenth century, immigration from Ireland, Germany and the UK predominated, followed by Canada and Scandinavia. After the Great Famine a substantial share of the Irish population migrated to the United States. Average annual emigration increased dramatically in Great Britain after 1880 but the greatest share of emigrants was directed to Canada in this period. Emigration from Nordic countries like Norway, Sweden and Denmark can be considered to be largely due to the poor economic conditions of these countries in the second half of the nineteenth century. Then, at the eve of the twentieth century, US immigration has been dominated by Eastern and

\footnotetext{
${ }^{1}$ Data are taken fron the Historical Statistics of the United States (2006), quoted hereafter as HSUS. Until 1930, a large majority of the arrivals of alien passengers corresponds to the arrivals of US immigrants.
} 
Southern Europe: Italy, Russia, Austria-Hungary, Poland. There were significant differences in the Italian pattern of emigration: natives of Southern Italy mainly migrated to the East Coast of North America whereas North-Eastern workers represented the bulk of the Latin American immigration, especially in Argentina.

What were the consequences of mass migrations on the composition of the US population? Figure 4 shows the evolution of net immigration relative to the total population increase as well as the evolution of the foreign born population with respect to the total population. The first proportion has increased until the Civil War, then decreased and increased again until the eve of the Great War. Then, a dramatic drop occured. In this regard, immigration laws have been progressively more restrictive in the United States and limited the foreign inflow. After the first period of mass immigration, during which five million people left Europe to reach the New World, between 1924 and 1965 the Origins Quota Act greatly reduced the levels of immigration. This can be observed in the figure as starting shortly after 1920 when the legislation was implemented. The lowest level of net immigration with respect to the population growth was reached during the Second World War when strict immigration laws came into effect and also the volume of international trade declined. After Second World War, the ratio of immigration to population growth has gradually increased to reach the highest proportion ever observed in 2000.

The foreign born population relative to total population shows less important fluctuations: it slightly increases until 1900, then declines until 1960 and increases again. This will be an important point of the paper: as the latter proportion has 
hardly exceeded $15 \%$, one can conjecture a modest influence of mass migration on the US average stock of education, unless the gap between migrants and natives education has been very large. This will be investigated in next section.

\section{Computing Average Years of Schooling in the United States 1870-1930}

In this section we present the framework that enables the reconstruction of the US population by age and by country of origin between 1870 and 1930. It is based on a perpetual inventory of the flow of migrants by age and by country. Then we describe the data, and focus on underlying assumptions.

\subsection{Statistical framework}

We estimate average years of schooling among individuals aged 15-64 in the US population and in the population of US natives only. They are respectively noted $E_{t}^{T o t}$ and $E_{t}^{U S}$. We have

$$
E_{t}^{T o t}=\frac{\sum_{n, k} E_{n, k, t} P_{n, k, t}}{\sum_{n, k} P_{n, k, t}}
$$

where $E_{n, k, t}$ is average years of schooling of US population of age $n$ at time $t$ born in country $k$, and $P_{n, k, t}$ the corresponding population. By convention $k=0$ 
corresponds to the US natives, hence

$$
E_{t}^{U S}=\frac{\sum_{n} E_{n, 0, t} P_{n, 0, t}}{\sum_{n} P_{n, 0, t}}
$$

Data on education by age and by country $E_{n, k, t}$ are taken from from MorrissonMurtin (2008) as described below. Populations $P_{n, k, t}$ are not observed and are reconstructed via a perpetual inventory of net immigration. More precisely foreignborn populations are constructed recursively in the following way

$$
\begin{aligned}
P_{n, k, t} & =P_{n-1, k, t-1} S_{n, k, t}+F_{k} A_{n, k, t} \text { for } n, t \geq 2, k>0 \\
P_{1, k, t} & =F_{k} A_{1, k, t}
\end{aligned}
$$

where $S_{n, k, t}$ stands for the conditional survival probability at age $n$ and time $t$, conditionally on having survived until age $n-1$ (time $t-1), F_{k}$ the flow of net immigration from country $k, A_{n, k, t}$ the share of migrants of age $n$ from country $k$ at time $t$. Initial conditions on the population in 1820 have little influence in 1870 and are set equal to zero ${ }^{2}$. We assume that once they have immigrated to the United States, all populations from the various countries have the same survival probability as US natives, namely that

$$
\forall k S_{n, k, t}=S_{n, 0, t}
$$

\footnotetext{
${ }^{2}$ Only the $0-15$ population resulting from pre-1820 migrations could have an influence in 1870 . It will anyhow be very modest due to low life expectancy, the low share of children among immigrants at that date, and small flows of migrants relatively to those of the future decades.
} 
On the other hand, US native population, which includes children of immigrants, is given by

$$
\begin{aligned}
P_{n, 0, t} & =P_{n-1,0, t-1} S_{n, 0, t} \text { for } n, t \geq 2 \\
P_{1,0, t} & =B_{t} S_{1,0, t}
\end{aligned}
$$

where $B_{t}$ is the number of births. In 1820 we make the simplifying assumption that US citizens are all natives, hence we confound the US age pyramid with the US natives age pyramid. In a further section we describe accurately the treatment of missing data.

\subsection{Data description}

The data have been extracted from the Historical Statistics of the United States (2006), Ferenczi and Willcox (1929 a,b) and Morrisson and Murtin (2008). The record of immigration started in the United States in 1819 as a result of the Steerage Act, which required the master of each vessel reaching the United States to declare name, age, sex and occupation of each passenger (HSUS, notes on table Ad1-2). This record represents an invaluable source of information even though the record of immigrants has changed over time ${ }^{3}$.

\footnotetext{
${ }^{3}$ For the flow of immigration we used the net flow of immigrants as calculated by the US Census (HSUS Table Aa9-14), which is based on Kuznets-Rubin from 1870 (HSUS Table Ad2124); for countries shares, we used data on immigrants by last country of residence (HSUS Table Ad106-120) to proxy the origin country, as those series are the only one to go back in time as far as 1820; foreign-born population by country of birth are taken from HSUS Table Ad354-443; US immigrants by age are taken from Table Ad226-230 (HSUS) where age groups have been homogeneized across time and statistics have been smoothed with a 10 years moving average; age
} 
The major emigration countries were retained and some were aggregated. At last we created eleven groups: Austria-Hungary, Canada, France, Germany, Ireland, Italy, Mexico, Poland, Russia-Finland, Sweden-Norway, the United King$\mathrm{dom}^{4}$. As a result, the total flow of immigrants from the retained countries represent $95.8 \%$ of total US immigration over the period 1820-1924 according to Ferenczi-Willcox (1929, v.1 p.178). Migrations from Asia and some small European countries were neglected.

We present hereafter the data used in equations (1-4). In the first section Figures 2 and 3, we have already described the distribution of migrants by country of origin $F_{k}$. Figure 5 shows how the US survival probabilities $S_{n, 0, t}$ have changed over time. There are important differences between the survival probability at age 15 and the survival probability at age 40 conditional on survival at age 15 until 1880. This was mainly due to the very low life expectancy of the US population and the very high infant mortality rates. Racial differential in mortality was also important with the Afro-American population exhibiting shorter life expectancy throughout all the period considered (for instance in 1910 the differential between the number of infant deaths per 1,000 live births was 46).

Between 1850 and 1880, life expectancy fluctuated, ${ }^{5}$ mainly as a result of the pyramids of immigrants from other countries are taken from Ferenczi and Willcox (1929a) where age groups have been homogeneized.

${ }^{4}$ In flows of migrants and foreign-born populations, Austria-Hungary also included Czechoslovaquia, Albania and Yugoslavia; France included Belgium and Netherlands; Italy included Greece, Portugal and Spain; Mexico included Latin American countries and Caraibes; Russia-Finland included Bulgaria, Baltic countries, Romania and Turkey; Denmark was added to Sweden-Norway. Corresponding figures for education are population weighted averages. The names of the groups derive from the major emigration countries among them.

${ }^{5}$ Fogel (1994) observed a decline in life expectancy between 1800 and 1860 and after a gradual 
periodic epidemics and changes in the disease environment. The turning point suggests that around 1880 the survival probability of the young population has progressively improved, reaching 0.85 in 1920 . It is not clear why 1880 happens to be the turning point, but what is agreed upon by historians and demographers is that "a new era in mortality history began around 1880"(Preston (1977, p. 165)

Data on average years of education $E_{n, k, t}$ are depicted on Figure 6 for some European countries and are issued from Morrisson and Murtin (2008). They use Mitchell data (2003a,b,c) and estimate by perpetual inventory methods the average years of Primary, Secondary and Tertiary schooling in 74 countries since 1870 . As many early enrolment figures were missing in the latter source, the authors used Lindert (2004) as a secondary data source.

In Europe, Germany had an edge on the other countries in terms of average years of schooling throughout the period. This is the outcome of early high enrolment rates in Primary schooling, especially in Prussia. On Table 1 the diversity of educational levels across emigration countries is striking. Four large emigration countries - Germany, Sweden, Norway and the United Kingdom - had high levels of schooling in 1870 , about 4.5 years on average. This roughly means that $75 \%$ of the population received 6 years of Primary schooling, or in other words increase by considering the overall population.

${ }^{6}$ Many factors seem to have played a role. First, the rapid mortality decline can be explained by advances in living standards and better living conditions, improvements in the germ theory of disease and certainly in the treatment of early-life disease. According to Nugent (1992, p.23) quoting a case study of Philadelphia over 1870-1930, epidemic diseases like smallpox, scarlet fever and typhoid fever were no longer causes of death. Also, according to the latter author the United States by the 1880s had reached a modern demographic regime with lower birth and death rates. 
that the illiteracy rate was about $25 \%$. On the other hand, Ireland, Central Europe and Italy were lagging behind in 1870, with an educational level smaller than 3 average years of schooling.

It is also important to notice the change between 1870 and 1930. All countries experienced a significant increase over these fifty years as a result of the implementation of gradual schooling reforms from the mid-nineteenth century such as the introduction of compulsory schooling. Countries that started from lower levels experienced the greatest increase: in Italy and Russia the estimated average years of schooling increased by more than four times, in Ireland by more than three. In Austria-Hungary and France the estimated stock of schooling doubled, whereas in those countries which exhibited high levels in 1870 the increase was more limited. In other words, convergence in years of schooling did occur during that period, albeit not uniformly.

\subsection{Assumptions}

Some missing information in the data sources previously described led us to make some assumptions. One of them is that immigrants were representative of their home-country fellows in terms of average education. Second, missing data on enrolment at school in emigration countries had to be supplemented by data interpolations in Morrisson and Murtin (2008). How influent are these interpolations will be discussed below. Last, there are some missing data on age pyramids of migrants and some unaccuracies in data of flows of migrants by country. Both will be corrected using additional information taken from HSUS. 


\subsubsection{Education of migrants}

A limited stream of the literature has looked at the characteristics of migrants. Greenwood (2007) has looked at the age composition of US immigration and found that the majority of migrants came from countries with a significant share of the labor force in the primary sector and also with relatively low birth rates. Baily (1983) and Erickson (1990) looked at the occupation of migrant workers. They found some regularities in the ethnic group concentration across different occupation. This is possibly one of the most revealing and valuable pieces of socioeconomic information as occupation and wages provide information on both the level of skills of the migrants and their market reward. Sandberg (1979, "the impoverished sophisticated") showed how people from the Nordic countries were on average more educated than the other immigrants.

According to Williamson (2006), migrants were positively selected in two ways. First, in terms of schooling: the evidence shows that immigrants from five European countries to the United States between 1899 and 1909 exhibited higher literacy rates than the average population that remained at home (Williamson, 2006, p.22). Moreover, immigrants were also positively selected in terms of innate abilities. That is, there was a positive selection in terms of motivation, entrepreneurship, persistence and possibly with respect to other non-cognitive skills. The over-representation of immigrants born between 1816 and 1850 among the most successful businessmen supports this argument (Williamson, 2006, p.22).

As average years of schooling of migrants are obviously not available, we will document this important question by focusing on occupations. For a handful 
of countries, we have indeed some information on the share of migrants among the emigrating population who work in the agriculture sector. For each country, we can compare this proportion to the national share of population working in agriculture. It will tell us whether people from the primary sector are over or under-represented in the emigrating population. As the bulk of illiteracy was concentrated in rural areas, it will provide some suggestive evidences on how education of migrants compares with the national average ${ }^{7}$.

Table 2 reports the results. As visible, the evidence is scarce: 25 countryperiod cells in total. It turns out that in Germany over the whole period, Italy in 1880, Finland in 1910 and Norway after 1910, both percentages are quite similar. In all other countries excepted Austria, the percentage of workers in agriculture is much lower in the emigrating population than in the country in general. Briefly, farmers were less mobile. This is particularly marked in Norway, Sweden and the British Isles.

To sum up, this suggests that farmers were under-represented in the migration population, and consequently that national average schooling constitutes most likely a lower bound of migrants' educational level. However, as this paper will argue that mass migrations have entailed a modest impact on the US average schooling level, we keep this assumption as a benchmark. It can be viewed as

\footnotetext{
${ }^{7}$ Unfortunately, it was not possible to compare the share of industry and services as classification turned out to be inconsistent between our two data sources: Ferenczi-Willcox (1929) for migrants, Mitchell (2003,a-b) for national figures. Mitchell acknowledges in preambule that the building of such classification was difficult. He relies on the work of Bairoch et al. (1968), who wrote: "because of the frequent changes in criteria and methods used in census taking...it is practically impossible to come up with statistics that are perfectly comparable in time and space".
} 
a conservative assumption in the sense that it probably slightly underestimates immigrants educational level, hence overestimate their negative impact on US average schooling.

\subsubsection{Education in emigration countries}

Inferring average schooling of the population aged between 15 and 64 in 1870 requires the knowledge of past enrolment rates between 1810 and 1860 when a perpetual inventory method is used. As shown by Table 3, countries differ in the extent of available information on enrolment. For Austria-Hungary, France, Germany, Italy, the United Kingdom and the United States enrolment figures were available as soon as 1830 thanks to Lindert (2004). These are the countries for which we have an accurate knowledge of average schooling in 1870 . For other countries, the first observation generally appeared in the course of the nineteenth century, with Poland being an exception as enrolment is unknown until 1922. For these countries, Morrisson-Murtin (2008) used ad-hoc assumptions on the enrolment rates in 1820 and conducted a linear interpolation with the first observation. If the first observed enrolment rate is low, as it is the case in Mexico and Finland, then the measurement error will be of modest magnitude. Indeed, enrollment has likely remained at very low levels between 1820 and the first observation ${ }^{8}$. If the first observed enrolment rate is high, as it is the case in Canada and Scandinavia, then the measurement error can be much higher.

\footnotetext{
${ }^{8}$ An examination of enrolment series for 74 countries demonstrate that growth in the enrolment rate has been a common rule in any continent at any time, with a few exceptions occurring during wars and the Great Depression.
} 
The latter authors adopted the strategy of bounding this measurement error: they calculated average schooling from 1870 in two extreme scenarios, one where all past enrolment rates are equal to the first observed rate, another where enrolment increases in the immediate past of the first observation at the highest speed observed worldwide over the period 1820-1960 (+2\% of enrolment rate in Primary per year). The first scenario overestimates average schooling in the adult population, and on the contrary the second scenario underestimates average schooling. This therefore leaves us with a confidence interval for all countries, which is reported on Table 1.

As expected, this confidence interval is very narrow in France, Germany, Italy and the United Kingdom. It is much larger in Canada, Ireland, Mexico, Scandinavia, and above all Poland. However, Mexico and Poland excepted, the width of the confidence interval has shrunk to 0 in 1930 . This simply reflects that one has information on any cohort of age.

In the following, we will use the upper and lower bounds of average schooling of the various cohorts of age in order to gauge the measurement error that possibly contaminates the US average schooling figure because of unknown European enrolment rates.

\subsubsection{Flows and Age Pyramids of Migrants}

Some information on flows of migrants was corrected and some on age pyramids of migrants was missing. As reported by the second column of Table 3, age pyramids of immigrants start being available in 1850 in Austria-Hungary, 1860 in 
France and Ireland, 1870 in Germany, Italy and Scandinavia, and 1900 in Finland. Except for Italy, they are available on a decennial basis until the mentioned year. So there is no data for the first half of the nineteenth century. However, we have access to the age pyramids of migrants in the US regardless of their nationality. We therefore make the simplifying assumption that immigrants from all countries were distributed along the same age pyramid until 1840, the average age pyramid of US immigrants. Then we interpolate with the first observed age pyramid. This procedure is applied to Austria-Hungary, France, Germany, Ireland, Italy, Finland and Scandinavia.

There are four countries for which no data, or very scarce data, are available. These countries are Canada, Mexico, Poland and the United Kingdom. So we have to form some ad-hoc assumptions on the age pyramids of their migrants. In this regard, we have at our disposal two additional sources of information that enable us to calibrate the assumptions adequately: the average age pyramid of US migrants and total foreign-born population by country. In practice, we compare these data with those stemming from our simulations and calibrate our assumptions in order to minimize the distance between predicted and observed variables ${ }^{9}$.

\footnotetext{
${ }^{9}$ More precisely, we interpolated the flow of migrants from Poland between 1894 and 1920 as it was missing in the data. Foreign-born population from Austria-Hungary turned out to be largely overestimated with very high flows of migrants between 1874 and 1894; we applied an adhoc statistical correction, lessening those flows by 30\%, which fit the corresponding foreign-born population; Mexican immigration is known to be under-reported (see notes of HSUS Table Ad1-2) with a share of US immigration smaller than $0.5 \%$ between 1835 and 1910; we interpolated this share over the latter period, augmenting it at about $2 \%$. The UK had only sparse data (the share of children 0-14); so we assumed that its age pyramid was intermediary between that of Germany, where the share of children is high, and Ireland, where the latter share is low, reflecting a blend of familial and economic migrations. Canada was inputed the average US age pyramid. Data on Italy were sparse between 1870 and 1920 and were unable to account for the prewar peak in adult
} 


\section{Results}

\subsection{The US population by age and country of origin}

Let us present first the results of the latter calibration exercise. Averaging over the country dimension $k$, one obtains $A_{n,,, t}$ the simulated age pyramid of migrants regardless of the country of origin. It is compared with the observed one on Figures 7 and 8, and the fit turns out to be almost perfect. This supports the view that the procedure has successfully captured the age dimension of migration flows by country. The graph depicts the high level and slow decline of the proportion of children aged 0-15 among US immigrants over the period 1840-1880, then its massive drop until First World War, and its afterwar recovery. Similarly, we capture the rise in the proportion of young adults among US immigrants in the late 1890s, and its decrease after the war.

Second, by summing over age dimension $n$ one gets $\sum_{n} P_{n, k, t}$ the population born in country $k$ living in the US at time $t$, regardless of its age. All data are summarized into 5 years averages. Figure 9 reflects the very good performance of the procedure overall as well as in individual cases; indeed, the correlation between predicted and observed foreign-born populations appears to be very high: so in addition to the age dimension, our procedure captures the origin country dimension of migration flows. Only the Polish population, and the Mexican one in a lesser extent, seem to have been underestimated; not surprisingly the United this period, as witnessed by the share of 0-14 children in 1900 and 1910. 
Kingdom is somewhat problematic for several quinquennial periods. But overall, the correlation between predicted and observed populations is very high. As shown by Table 3, eight countries over eleven have a level of correlation higher than 0.9 . The average correlation is 0.94 .

Besides, there seems to be no significant bias in the measurement errors of total populations. Figure 10 plots the empirical distribution of the relative measurement error on total populations, estimated with a Gaussian kernel. Its mean is 0.16 and its standard error 0.70 . Its positive mean can be explained by the existence of some outliers on the right tail, corresponding to negligeable populations that generate large relative errors.

As expected, the foreign-born population is well captured as proved by Figure 11. This graph also shows that the total US population is well estimated, albeit some slight overestimation in the afterwar. This indicates that the US native population is well reproduced by the a simple dynamical system based on the knowledge of births and quinquenial survival probabilities. The outflow of US emigrants to Canada seems to be therefore negligeable.

Table 4 addresses the age structure and relative importance of the various groups. The share of the country-born population in US population in 1870 (first column) is a good indicator of the timing of migration. As expected, Germany, Ireland and the UK constitute the bulk of foreign-born population at that date. Sixty years later, the foreign-born population is much more diverse as the largest group of immigrants, Italians, represent only $2.1 \%$ of the US population. However, this imperfectly reflects the relative shares of "communities" as children of 
migrants born in the US are classified as Americans. The share of young adults is very high in most countries, but it varies across countries. This is related to the type of migration. In 1870, countries like Austria-Hungary, Germany, Italy and Sweden had a high proportion of children and this is explained by the "familial" type of immigration whereas Ireland represents the "economic" type of immigration, which prevailed at the end of the period.

\subsection{Education in the United States 1870-1930}

Let us now turn to our final result, presented in the last Table and graph. The confidence interval of US average years of schooling deriving from uncertain enrolment rates in Europe is reported on Figure 12 and is very narrow. This figure also reports the average years of schooling as inferred from the first national survey by the US Census from 1940. Census estimates are fully in line with our serie and extrapolate it naturally in 1940, 1950 and 1960. It is a strong confirmation that our procedure has derived some credible series of average schooling among the US population.

Table 5 shows for the first time the average education of US natives, of US immigrants and of US population for both the 15-64 and the 15-39 age groups over the period 1870-1930. It also reports the discrepancy between immigrants and natives average education. It is no mystery that US natives were more educated: the gap is equal to 2.54 average years of schooling in 1870 , equivalent to a $30 \%$ enrolment rate gap in an 8-years long Primary. This discrepancy is important, but the composition effect is limited because the foreign-born population aged 
between 15 and 64 years weighted $25.6 \%$ of the 15-64 US population, a share that continuously decreased to reach $15.6 \%$ in 1930 . As a result, average schooling in the US is diminished from 6.22 years to 5.57 years in 1870 , or a 0.65 years gap - approximatively $8 \%$ of Primary enrolment rate in the population. This gap is significant, but somewhat modest. We find the same result in the young adults population: immigrants had on average 4.08 years of schooling versus 6.53 for the natives of the same age group, a 2.45 years gap. The compositional impact was a reduction of 0.79 average years of schooling on the 15-39 US population.

Interestingly, the discrepancy between 15-64 US natives and immigrants has continuously increased from 1885 . Similarly, a look at the $15-39$ population reveals that the educational gap among young adults has decreased in the 1870s, then rised again and peaked at a very large 4.27 value in 1920. This represents more than a 50 percentage points discrepancy in enrolment rates in a 8-years long Primary between natives and immigrants.

How do the latter figures compare with early evidence on educational attainment in the US? Although many sources do exist (e.g., state level administrative records, US census, state censuses and Current Population Survey) they are not available for each geographical area the level of accuracy ${ }^{10}$ varies across states (Goldin, 1999). The 1915 Iowa State Census represents an exception to the paucity of data available ${ }^{11}$ The state of Iowa started twenty-five years earlier than

\footnotetext{
${ }^{10}$ In this regard, statistics are not consistently recorded across states (e.g., in some states enrollment rates have been recorded only for some age-groups, some education data series folow the school rather than the calendar year) and more in general these education data do not show the "years of schooling" of the population and appear inflated when comparing these to the actual occupations.

${ }^{11}$ Also, the state of South Dakota adopted the same model to record the educational level of the
} 
the other states to introduce questions on educational attainment in the census. Moreover, the 1915 Iowa State Census sample is large and derived from a true population census ${ }^{12}$. According to Goldin and Katz (2000) the Iowa State is representative for the United States as educational wage differentials follow a similar trend between 1940 and 1960. As a matter of facts, Iowa estimates are roughly consistent with our figures. That is, average years of schooling for men, 25-49 years-old, were equal to 8.61 and to 8.98 for women in Iowa in 1915 (Goldin and Katz, 2000, Table 1). At the same date, we calculate average years of schooling for the 15-39 age band to be equal to 8.71 for US natives and 7.67 when migrants are taken into account. As the latter authors acknowledge that the occupations in Iowa were not representative of occupations at national levels, these figures appear to be consistent with each other.

\section{Immigration Laws, Education and the}

\section{Americanization Process of Immigrants}

Immigration was nearly unrestricted in the nineteenth century ${ }^{13}$. Things came to an end at the turn of the century when a series of laws were implemented to limit the number of immigrants. The new legislation aimed at increasing the num-

population.

${ }^{12}$ For an extensive review of the data sources over the nineteenth century, please refer to the Historical Statistics of the United States and Goldin (1999).

${ }^{13}$ With the exception of the 1882 Chinese Exclusion Act which imposed restrictions on immigration from Asia. According to Foreman-Peck (1992), this restriction was motivated by the fact that workers from Asia were mainly unskilled and would have substituted the American labor force rather than complementing domestic labor. 
ber of excludable categories by banning Asians, imposing passport requirement, and introducing a sort of selection on the quality of immigrants. In an insightful analysis Goldin (1994) examines the driving forces leading to the restriction of immigration and shows how both labor and capital turned against immigration as a result of the depression of the 1890s. O'Rourke and Williamson (2000) complement this analysis by separating the short and long-run fundamentals that led to the restriction of immigration. The passage of the legislation anti-immigration was concentrated in less than ten years and three Acts represent the core of the change in policy.

First, with the introduction of the Literacy Test in 1917, immigrants were required to read and write a language which did not have to be English. This piece of legislation was the result of the report of the Immigration Commission headed by Senator William Dillingham which concluded that the new immigrants, who came from Italy, Poland, Hungary, Russia and Eastern Europe, did not assimilate as easily as the ones who were coming from Northern and Western Europe during the previous wave of immigration. Goldin (1994) explains how calls for the literacy test were given serious consideration much earlier than the text became law in 1917. In fact, as early as in 1897 the proposal passed the House and the Senate but received a presidential veto. The same author explains how the literacy test was implemented at a time when literacy was rising rapidly in Europe (Goldin, 1994, p.226). Consequently, other active policy measures became necessary to impose a restriction on the immigration flow.

Second, the Emergency Quota Act of 1921 by imposing restrictions based on 
the nationality of immigrants marked a significant change in the U.S. immigration policy. In this regard, the policy became much more restrictive, that is only a number equal to three percent of the number of foreign-born residents of each nationality who were living in the United States as recorded by the 1910 census was allowed to enter the United States.

Third, the Immigration Act of 1924 was even more restrictive as it lowered the quota to two percent and used the 1890 census. It aimed at keeping the current ethnic distribution and was a response to the increased immigration from Southern and Eastern Europe. The Act reduced the number of U.S. immigration visas and allocated them on the basis of national origin. It introduced a distinction between quota-nations and non-quota nations. As a result, only 4000 Italians per year were allowed to enter, while annual flows were about 200000 per year between 1900 and 1915. In contrast, 86\% of the 165000 permitted entries were from France, Britain, Germany and other Northern European countries.

What were the economic motives behind the implementation of the latter restrictions? Timer and Williamson (1997) argue that the change in attitude towards immigration has been a result of the change in quantity and quality of the foreign labor supply. That is, policy became more restrictive as a result of the increased immigration rates and the increase in the proportion of workers coming from lower-wage and lower human capital countries of Europe. Because it created more inequality, especially at the bottom of the income distribution, immigration was a source of social unrest. They find that the most important factor for the United States was the ratio of the unskilled wage to per capita income. That is, 
the main determinant of the switch in policy was the deterioration of the labor market conditions. This reflected the interests of the low-skilled workers who were against immigration as opposed to the interests of capital owners who supported immigration as this could have granted them access to cheaper labor force. Therefore, as a result of the widening of the income gap between unskilled and skilled workers, policy makers implemented a more restrictive immigration legislation to protect the interests of the unskilled labor. The authors also find that the quality of immigration has been more important than the quantity of immigration in determining the policy change, that non-economic variables do not have much explanatory power, and that policies were correlated across countries in the New World.

Another argument supports the view that the low quality of immigration was the key factor behind migration laws: continuous flows of young illiterate immigrants might have jeopardized the rising high school movement and the ongoing Americanization process. As described extensively by Goldin (1999), enrolment in high school accelerated in the 1920s, exactely at the same time immigration laws were implemented. Policy makers emphasized the process of Americanization at the time, a process that relied on investments into immigrants' children education. Before World War I, Americanization was part of the Progressive movement's broader efforts to construct a modern and cohesive social order, and also part of a new national effort to cultivate patriotism among all Americans. Therefore, one of the main objectives was to ensure the adherence to "American" cultural norms. According to Claxton (1920, p.622) "Americanization [wa]s a 
process of education, of winning the mind and heart through instruction and enlightenment" and according to Thompson (1920, p.582), "America [wa]s looking forward with anxious hope to the school as the chief instrument for Americanization". These quotes are revealing of the great importance that was attached to education in the process of americanization. In this regard, in the early 1900s public schools began to adopt extra-curricular activities to introduce immigrants to the American values, beliefs and overall culture. With the beginning of World War I, the movement of Americanizing the immigrant became even more widespread (Atzmon, 1958, p.76). From 1914 to 1920 the Bureau of Naturalization of the Immigration and Naturalization Service set invitations to more than 200,000 naturalization applicants and their wives for them to attend English classes and the essentials of good citizenship (Atzmon, 1958, p.76). This "quest for conformity" (Carlson, p.623) was central to the American society before 1930 as Americans had great faith that education and other organized forms of social control could transform other immigrants into productive citizens. In that respect, uneducated immigrants were certainly a problem for lawmakers who expressed a desire for a more homogeneous society. As the education of youth was significantly raised at the time, ensuring a proper Americanization of immigrants' children, flows of unskilled migrants were certainly counter-productive from that perspective, and one would conjecture that this political factor was partly responsible for the implementation of immigration laws. 


\section{Conclusion}

This paper assesses the impact of mass migrations on the average level of schooling in the United States over the period 1870-1930. We reconstruct the foreignborn population by age and by country of origin using data on age pyramids of migrants by country and flows of immigrants by country. Then we combine it to original data on educational attainment taken from Morrisson and Murtin (2007). As a result, we derive original series of average schooling over the period 18701930, which take into account the compositional effect of mass migrations. Importantly, our series are consistent with the first national value of average schooling obtained in 1940. Our results suggest that immigration is unlikely to have entailed large variations in the educational level of the US labor force because immigrants never represented more than $25 \%$ of the US workforce. However, the educational gap between immigrants and natives increased with the second wave of immigration. According to O'Rourke and Williamson (2000) mass migration and trade did play the critical role in contributing to convergence. Can these series help in refining their analysis by addressing the skill content of the workforce more accurately? We leave this question opened for future research. 


\section{References}

[1] Atzmon E. (1958). The educational programs for immigrants in the United States. History of Education Journal, vol. 9, no. 3, p.75-80.

[2] Baily S. (1983). The Adjustment of Italian Immigrants in Buenos Aires and New York, 1870-1914. American Historical Review, Vol. 88, No. 2, pp. 1305.

[3] Baines D. (1991). Emigration from Europe 1815-1930, prepared for the Economic History Society, London: Macmillan Press

[4] Bairoch, P. et al. (1968). La population active et sa structure, Bruxelles, Universite libre de Bruxelles.

[5] Cameron R. (1985). A New View of European Industrialization. Economic History Review, Vol. 38, No. 1, pp. 1-23.

[6] Carlson R. A. (1984). The Americanization Syndrome: A Quest for Conformity. New York: St. Martin's Press.

[7] Claxton P.P. (1920). What is Americanization?. Washington DC: Commissioner for Education's Report, pp.2-3.

[8] Erickson C. J. (1990). Emigration from the British Isles to the U.S.A. in 1841: Part 11. Who were the English emigrants?. Population Studies, Vol. 44, pp. 21-40. 
[9] Ferenczi I. and Willcox W. F. (1929a). International Migrations, vol. 1 Statistics, New York: National Bureau of Economic Research

[10] Ferenczi I. and Willcox W. F. (1929b). International Migrations, vol. 2 Interpretations, New York: National Bureau of Economic Research

[11] Fogel, R. W. (1994). Economic Growth, Population Theory, and Physiology: The Bearing of Long-Term Processes on the Making of Economic Policy, American Economic Review Vol. 84, No. 3, pp. 369-95.

[12] Foreman-Peck, J. (1992). A Political Economy of International Migration, 1815-1914. The Manchester School of Economic Social Studies, Blackwell Publishing, vol. 60(4), pp. 359-76.

[13] Goldin, C. (1994). The Political Economy of Immigration Restriction: The United States, 1890-1921. In C. Goldin and G. Libecap, eds., The Regulated Economy: An Historical Analysis of Government and the Economy. Chicago, IL: University of Chicago Press.

[14] Goldin, C. (1999). A Brief History of Education in the United States. NBER Working Paper, Historical Series no. 119.

[15] Goldin, C. and L. Katz (2000). Education and Income in the Early Twentieth Century: Evidence from the Prairies. Journal of Economic History (September 2000). 
[16] Greenwood, M.J. (2007). Modeling the age and age composition of late 19th century U.S. immigrants from Europe. Explorations in Economic History, 2007, vol. 44, issue 2, pp. 255-269.

[17] Hatton T.J and Williamson J.G. (1998). The Age of Mass Migration. Causes and Economic Impact, Oxford: Oxford University Press.

[18] Hatton T.J and Williamson J.G. (2005). Global migration and the world economy: two centuries of policy. MIT Press.

[19] Historical Statistics of the United-States (2006). Milennial Edition Online.

[20] Livi-Bacci M. (1991) Population and Nutrition. An Essay on European Demographic History, Cambridge: Cambridge University Press

[21] Lindert, P. (2004). Growing Public. Vol. 2. Cambridge U.P. Cambridge.

[22] Mitchell, B.R. (2003a). International Historical Statistics: the Americas 1750-1993. M.Stockton Press, New-York.

[23] Mitchell, B.R. (2003b). International Historical Statistics: Europe 17501993. M.Stockton Press, New-York.

[24] Mitchell, B.R. (2003c). International Historical Statistics: Africa, Asia and Oceania 1750-1993. M.Stockton Press, New-York.

[25] Morrison C. and F. Murtin (2008). The Century of Education. Paris School of Economics Working Paper. 
[26] Nugent W. (1992). Crossings, The Great Transatlantic Migrations, 18701914. Bloomington Indianapolis: Indiana University Press.

[27] O'Rourke, K. H., A. M. Taylor, and J. G. Williamson (1996). Factor Price Convergence in the Late Nineteenth Century. International Economic Review, Vol. 37, No. 3, pp.499-530.

[28] O'Rourke, K. H. and J. G. Williamson (2000). Globalization and History: the evolution of a 19th century atlantic economy. Cambridge, Mass.: MIT Press.

[29] Preston S. H. (1977). Mortality Trends. Annual Review of Sociology, Vol. 3 , pp. 163-178.

[30] Ruggles S. and M. Sobek. (1998). User's Guide: Integrated Public Use Microdata Series: Version 2.0. Minneapolis: Minnesota Population Center, University of Minnesota.

[31] Sandberg, L. G. (1979). The case of the impoverished sophisticate: Human capital and the Swedish economic growth before World War I, The Journal of Economic History, Vol. 39, No.1, pp.225-241.

[32] Thompson F. V. (1920). The School as the instrument for nationalization, here and elsewhere. In Immigration and Americanization, P. Davis (ed.), Boston: Gynn and Company, pp.582-600. 
[33] Timmer, A. and J. G. Williamson. Racism, Xenophobia or Markets? The Political Economy of Immigration Policy Prior to the Thirties. NBER Working Paper No. 5867, January 1997.

[34] Williamson, J.G. (2006). Inequality and schooling responses. The Globalization forces: lessons from history. NBER WP 12553. 


\section{A Table}

Table 1 - Average Years of Schooling Among 15-64

\begin{tabular}{lcccccc}
\hline \hline & & \multicolumn{1}{c}{1870} & & & \multicolumn{1}{c}{1930} \\
& Estimate & Lower Bound & Upper Bound & Estimate & Lower Bound & Upper Bound \\
\hline Austria-Hungary & 2.4 & 1.8 & 2.7 & 4.9 & 4.9 & 4.9 \\
Canada & 4.5 & 4.2 & 7.0 & 8.6 & 8.6 & 8.6 \\
France & 4.0 & 4.0 & 4.2 & 8.0 & 8.0 & 8.0 \\
Germany & 5.4 & 5.3 & 5.4 & 7.9 & 7.9 & 7.9 \\
Ireland & 2.2 & 1.6 & 2.9 & 7.0 & 7.0 & 7.0 \\
Italy & 0.9 & 0.8 & 0.9 & 4.1 & 4.1 & 4.1 \\
Mexico & 0.6 & 0.0 & 1.5 & 1.6 & 1.4 & 1.6 \\
Poland & 1.7 & 0.1 & 4.4 & 4.5 & 2.8 & 5.2 \\
Finland & 0.5 & 0.1 & 0.7 & 2.0 & 2.0 & 2.0 \\
Sweden-Norway & 4.7 & 3.0 & 5.0 & 6.7 & 6.7 & 6.7 \\
United Kingdom & 3.8 & 3.8 & 4.1 & 6.8 & 6.8 & 6.8 \\
\hline
\end{tabular}


Table 2 - Share of Agriculture in Migrants and National Population Occupations

\begin{tabular}{|c|c|c|c|c|c|c|}
\hline & & 1880 & 1890 & 1900 & 1910 & 1920 \\
\hline \multirow[t]{2}{*}{ Austria } & Migrants & - & - & 59.1 & 62.8 & - \\
\hline & Natives & 51.9 & 57.1 & 53.3 & 48.8 & 32.4 \\
\hline \multirow[t]{2}{*}{ France } & Migrants & 38.4 & - & - & - & - \\
\hline & Natives & - & - & 43.4 & 40.3 & 38.6 \\
\hline \multirow[t]{2}{*}{ Germany } & Migrants & - & - & 36.4 & 28.1 & 21.9 \\
\hline & Natives & 42.6 & - & 35.7 & 28.4 & 23.6 \\
\hline \multirow[t]{2}{*}{ Italy } & Migrants & 44.3 & 52.1 & 41.7 & 32.0 & 41.9 \\
\hline & Natives & 54.0 & - & 58.2 & 54.2 & 54.8 \\
\hline \multirow[t]{2}{*}{ Finland } & Migrants & - & 77.0 & 74.1 & 65.2 & 49.0 \\
\hline & Natives & 72.4 & - & - & 69.0 & 67.8 \\
\hline \multirow[t]{2}{*}{ Norway } & Migrants & 8.2 & 16.1 & 23.9 & 42.1 & 35.8 \\
\hline & Natives & 38.6 & 56.0 & 48.0 & 48.6 & 43.5 \\
\hline \multirow[t]{2}{*}{ Sweden } & Migrants & - & 19.1 & 28.7 & 31.8 & 29.5 \\
\hline & Natives & 58.9 & 65.8 & 53.1 & 47.8 & 44.2 \\
\hline \multirow[t]{3}{*}{ British Isles } & Migrants & 6.5 & 9.4 & 7.0 & 7.8 & - \\
\hline & UK Natives & 17.6 & 14.7 & 12 & 11.5 & 9.2 \\
\hline & Ireland Natives & 40.6 & - & - & 42.9 & - \\
\hline
\end{tabular}




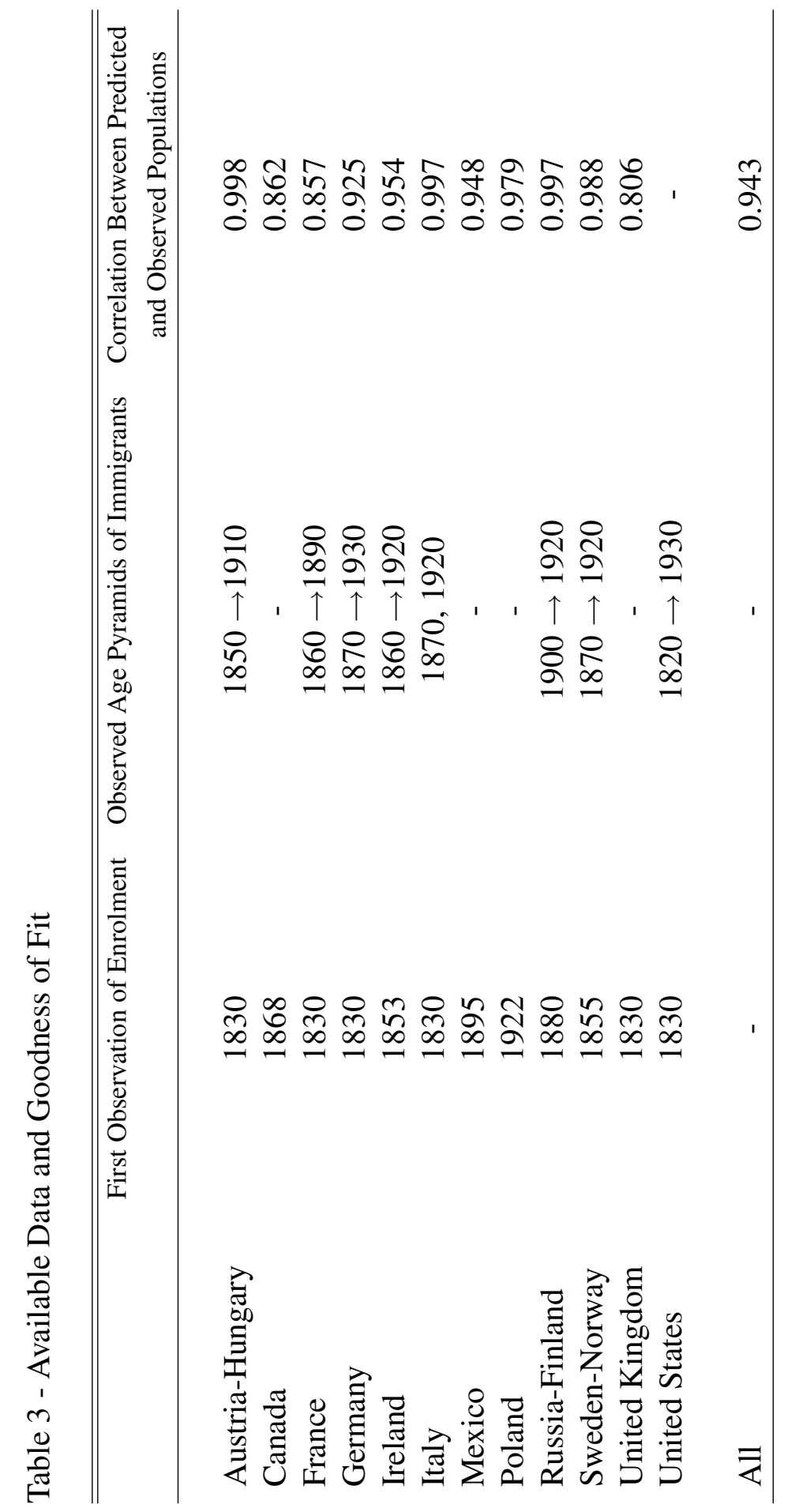


Table 4 - Immigrants Population Characteristics - Country Shares in Percents

\begin{tabular}{|c|c|c|c|c|c|c|}
\hline & \multicolumn{3}{|c|}{1870} & \multicolumn{3}{|c|}{1930} \\
\hline & Population Share $^{1}$ & Children $^{2}$ & Young Adults $^{3}$ & Population Share ${ }^{1}$ & Children $^{2}$ & Young Adults $^{3}$ \\
\hline Austria-Hungary & 0.0 & 21.8 & 55.3 & 1.3 & 1.0 & 31.6 \\
\hline Canada & 0.7 & 12.9 & 61.5 & 1.2 & 8.5 & 60.4 \\
\hline France & 0.8 & 5.4 & 48.0 & 0.3 & 5.5 & 37.2 \\
\hline Germany & 5.2 & 12.3 & 56.1 & 1.1 & 4.9 & 26.9 \\
\hline Ireland & 5.3 & 3.4 & 57.8 & 0.7 & 1.7 & 32.1 \\
\hline Italy & 0.1 & 10.6 & 53.3 & 2.1 & 2.7 & 40.0 \\
\hline Mexico & 0.4 & 8.0 & 53.4 & 0.6 & 8.9 & 58.5 \\
\hline Poland & 0.0 & 3.9 & 19.0 & 0.7 & 3.2 & 50.5 \\
\hline Russia-Finland & 0.0 & 3.5 & 14.8 & 1.5 & 0.6 & 37.9 \\
\hline Sweden-Norway & 0.5 & 20.8 & 52.9 & 0.8 & 2.0 & 31.0 \\
\hline United Kingdom & 3.3 & 10.1 & 59.6 & 1.0 & 2.9 & 38.3 \\
\hline All & 16.4 & 8.8 & 56.8 & 11.1 & 3.4 & 39.9 \\
\hline
\end{tabular}

${ }^{1}$ Share of the country-born population in US population

${ }^{2}$ Share of the country-born children population (0-14) in country-born US population (0-64)

${ }^{3}$ Share of the country-born young adults population (15-39) in country-born US population (0-64) 


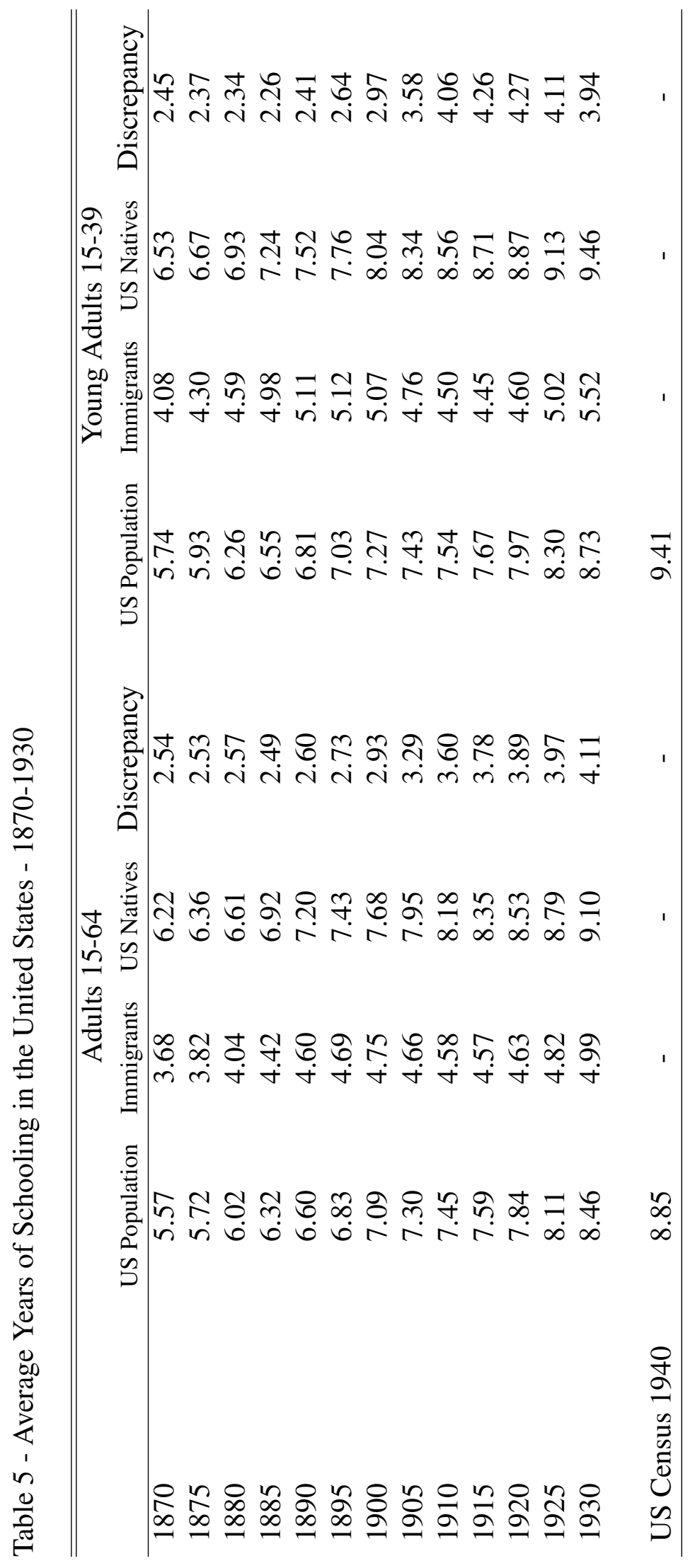




\section{B Figures}

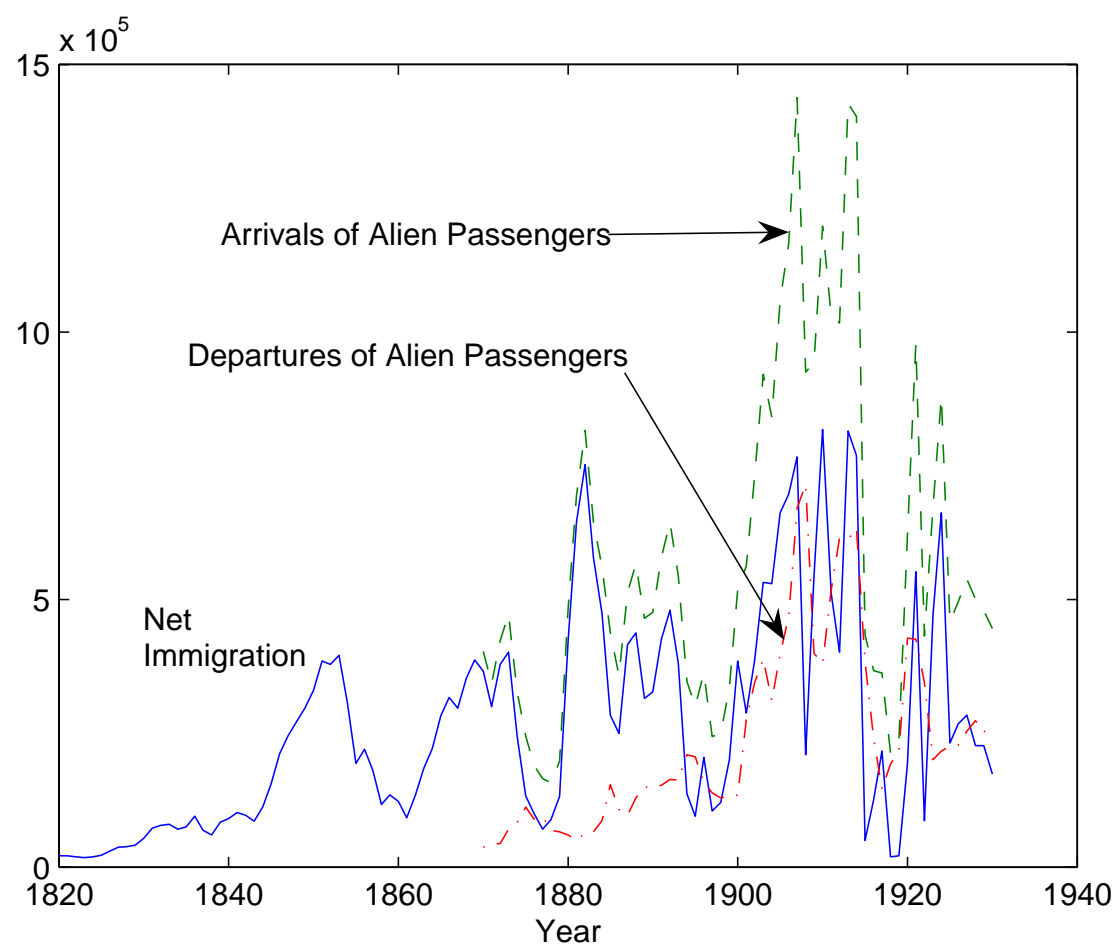

Figure 1: Arrivals, Departures and Net Immigration 


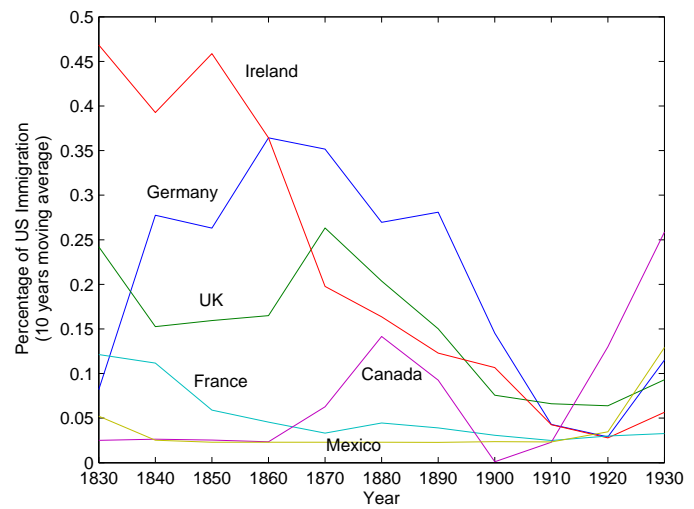

Figure 2: The First Wave of Immigration

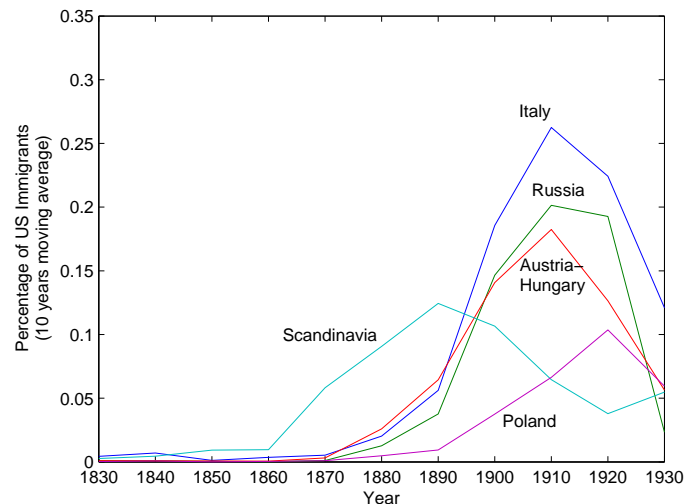

Figure 3: The Second Wave of Immigration 


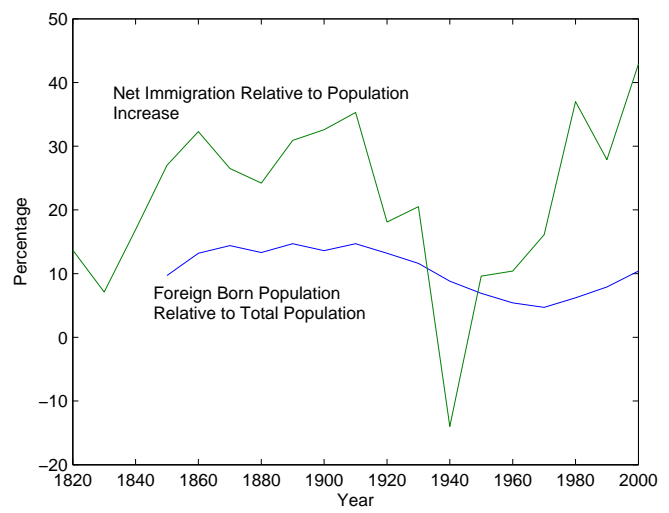

Figure 4: Immigration as a Proportion of US Population - Stock and Flow

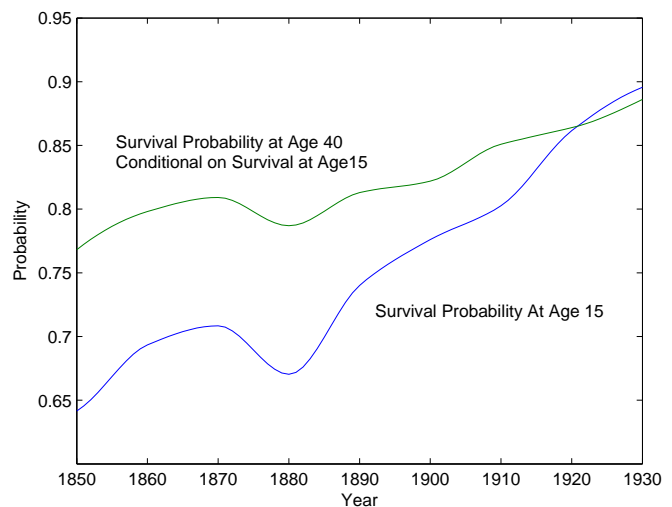

Figure 5: Survival Probabilities of the US Population 


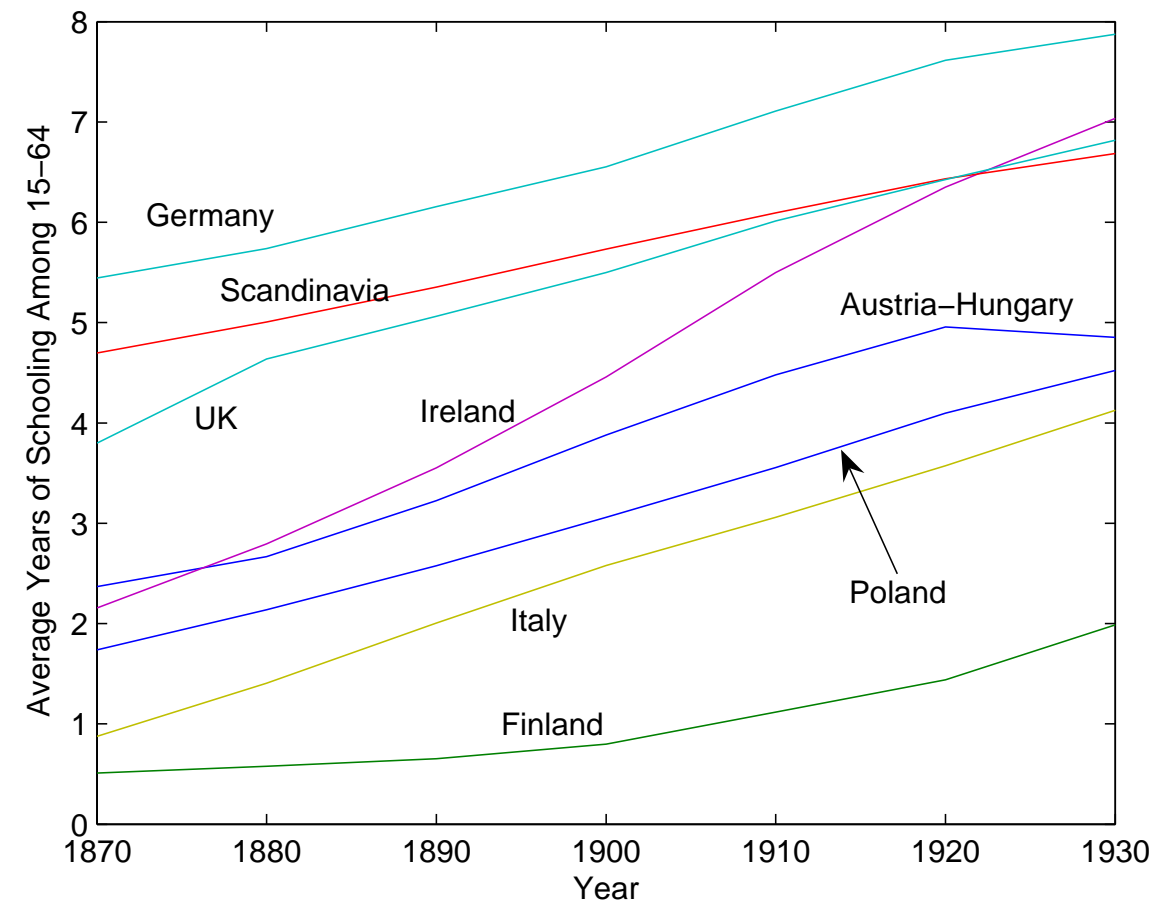

Figure 6: Average Years of Education in European Immigration Countries 


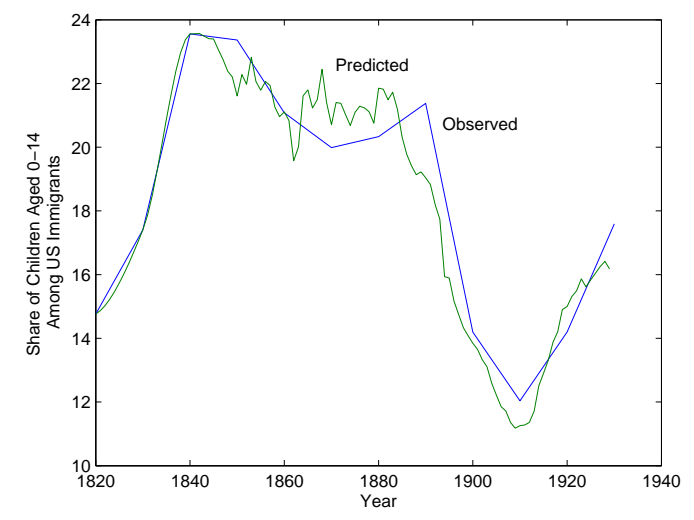

Figure 7: Observed and Predicted Shares of Children Among Immigrants

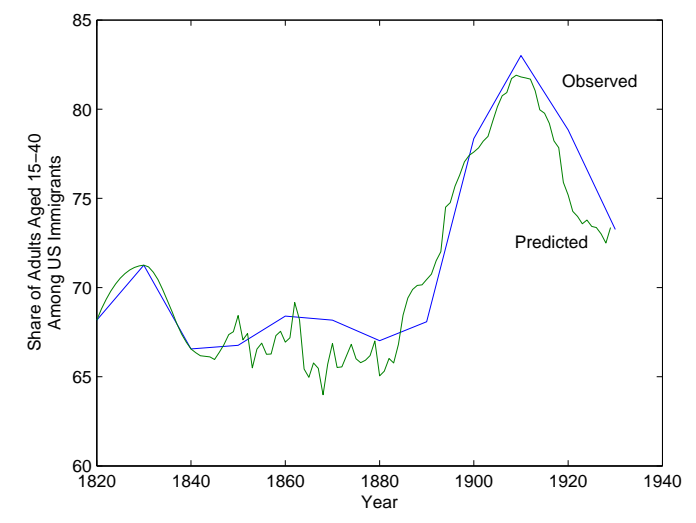

Figure 8: Observed and Predicted Shares of Young Adults Among Immigrants 

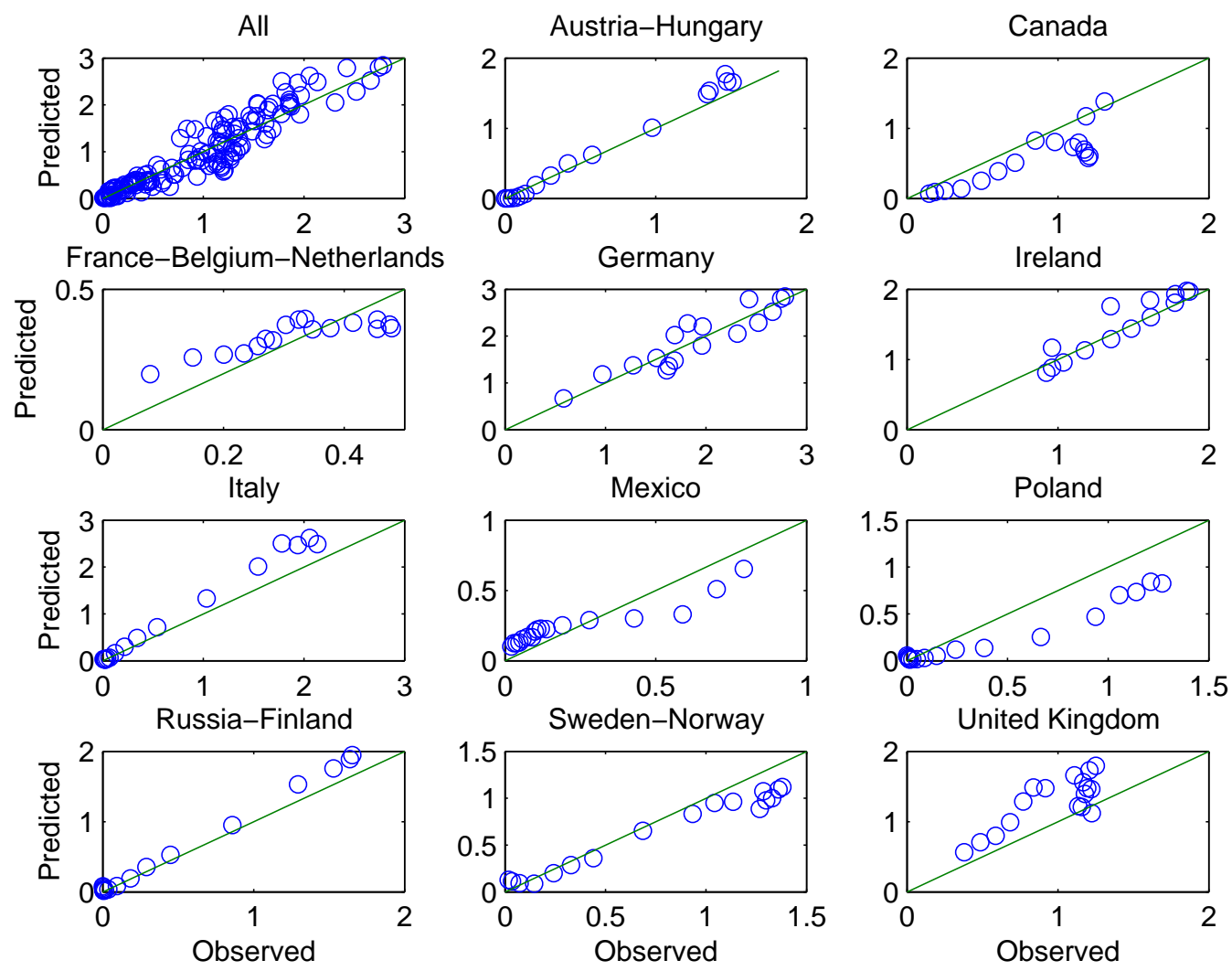

Figure 9: Comparison of Predicted and Observed Total Populations by Country (Population 0-64 in millions, quinquennial periods 1870-1930) 


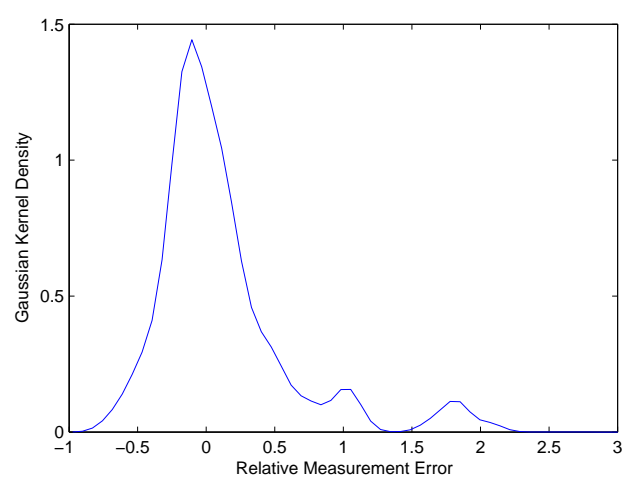

Figure 10: Empirical Distribution of Populations Measurement Error - Gaussian Kernel Estimate

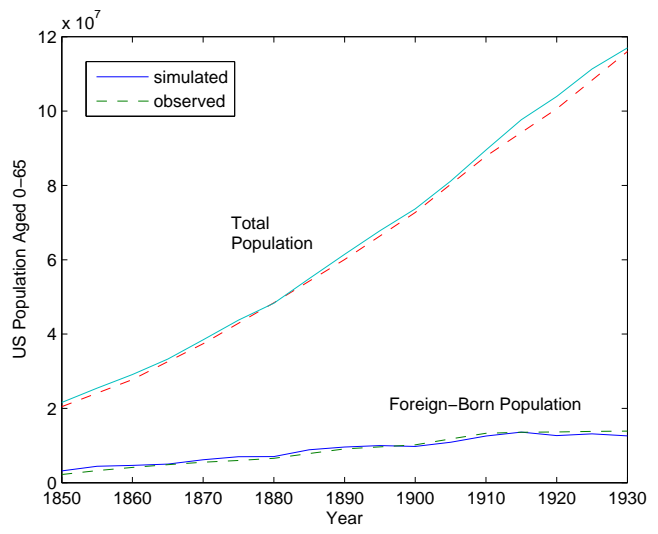

Figure 11: Comparison of Simulated and Observed Populations 


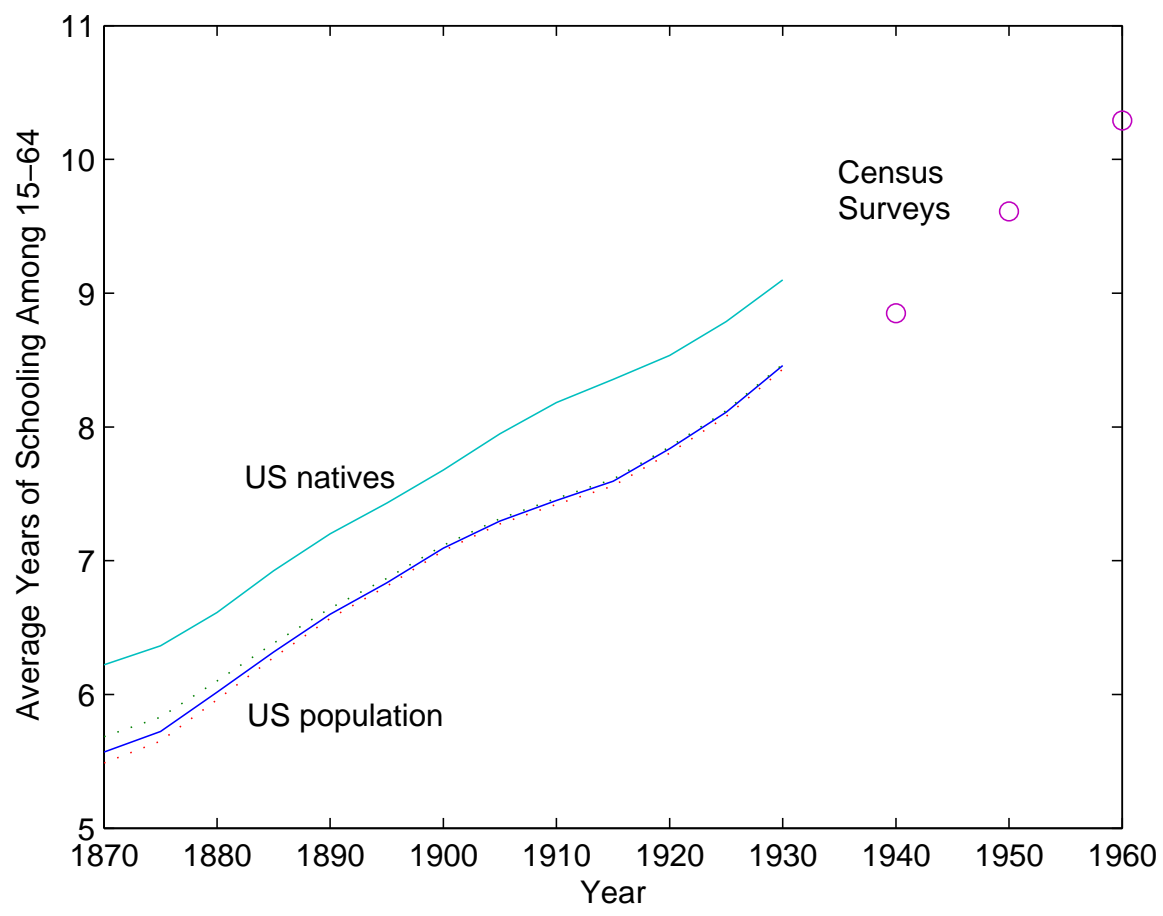

Figure 12: Average Years of Schooling Among Adults 15-64 